\title{
MANIFESTASI GENDER DALAM STRUKTUR BUDAYA SPIRITUAL MASYARAKAT TOANI TOLOTANG
}

\author{
Nensilianti \\ Fakultas Bahasa dan Sastra, Universitas Negeri Makassar \\ Jalan Daeng Tata Raya, Kampus Parangtambung, Universitas Negeri Makassar \\ email: nensiliantisaila@yahoo.co.id.
}

\begin{abstract}
The Manifestation of Gender in the Culture Structure of Toani Tolotang Communities. This study aimed to describe the status, roles, and gender inequality in the cultural structure of Toani Tolotang communities. Collecting techniques of the data are through observation, indepth interviews and focus group discussions. The results showed: (1) the manifestation of the injustice caused by differences in the social strata (status quo) in society, namely: the impression of slavery, oppression and economic deprivation, restraint in decision-making, and differences in educational opportunities, (2) the manifestation of gender inequality caused by the beliefs of Toani Tolotang communities, namely: the feelings and individual decisions constrained by the status quo, the limitation of movement and productivity for pregnant women, the over loyalty of wife to husband, the unbalanced of sharing roles and workloads between men and women, and lack of respect for the work of women.
\end{abstract}

\begin{abstract}
Abstrak: Manifestasi Gender dalam Struktur Budaya Masyarakat Toani Tolotang. Penelitian ini bertujuan mendeskripsikan kedudukan, pembagian peran, dan ketidakadilan gender dalam struktur budaya masyarakat Toani Tolotang. Teknik pengumpulan dilakukan melalui observasi, wawancara mendalam, dan kelompok diskusi terfokus. Hasil penelitian menunjukkan: (1) manifestasi ketidakadilan yang disebabkan perbedaan strata sosial (status quo) dalam masyarakat, yaitu: munculnya kesan perbudakan, penindasan dan pemiskinan ekonomi, pengekangan dalam pengambilan keputusan, dan perbedaan kesempatan memperoleh pendidikan; (2) manifestasi ketidakadilan gender yang disebabkan oleh kepercayaan masyarakat Toani Tolotang, yaitu: perasaan dan keputusan individu dibatasi oleh status quo, pembatasan gerak dan produktivitas wanita yang sedang hamil, kesetiaan istri terhadap suami melampau batas, pembagian peran dan beban kerja wanita lebih berat, kurangnya penghargaan terhadap hasil kerja wanita.
\end{abstract}

Kata kunci: gender, kesetaraan pria-wanita, Tolotang

Salah satu suku/etnis yang sangat kuat dalam memegang dan mempertahankan kepercayaan dan tradisi leluhurnya adalah masyarakat Tolotang di Desa Amparita, Kecamatan Tellu Limpoe, Kabupaten Sidenreng Rappang, Sulawesi Selatan. Kepercayaan Tolotang merupakan kepercayaan asli yang kehadirannya tumbuh secara spontan dan anonim di tengah-tengah masyarakat setempat. Kepercayaan ini menjiwai kehidupan sosial budaya yang berkembang dalam masyarakat dengan sifat-sifat lokal dan nilainilai yang unik. Budaya masyarakatnya sangat berbeda dengan masyarakat sekitar, meskipun masih berasal dari rumpun etni yang sama, yakni etnik Bugis.
Kepercayaan Tolotang adalah milik bersama pada masyarakat setempat dan diwariskan secara turun-temurun, dihayati dan dikembangkan oleh generasi-generasi selanjutnya. Kebudayaan asli yang dijiwai oleh kepercayaan yang berpaham monoteisme (yang disebutnya Dewata Seuwae) itu didasari oleh pandangan yang bersifat kosmos.

Masyarakat Toani Tolotang tetap dengan teguh menaati stratifikasi mereka. Mereka mengenal sistem pelapisan (strata) sosial yang meliputi sanak keluarga pemimpin/bangsawan ( $u w a)$, lapisan orang merdeka/warga biasa (Tomarade$k a$ ), dan lapisan sahaya (Ata). Masyarakat Toani Tolotang memandang uwa-uwa mereka sebagai 
turunan dari orang suci sehingga keturunannya pun dianggap berbeda dengan kelompok masyarakat pengikutnya.

Kelompok sosial Toani Tolotang percaya bahwa mereka keturunan La Panaungi dan telah mewarisi kemampuan dan kekuatan yang telah dianugrahkan oleh Tuhan (Dewata SeuwaE). Hanya $u w a$ yang dapat berkomunikasi dengan $D e$ wata SeuwaE dan memohon kepadanya kesehatan dan kesejahteraan di akhirat. Warga biasa tunduk pada bimbingan $u w a$ dan senantiasa memohon petunjuk dalam hal urusan dunia maupun spritual kepada $u w a$.

Penyembahan kepada Dewata SeuwaE, menurut kepercayaan Toani Tolotang, tidak dilakukan secara langsung, melainkan dilakukan dengan upacara ritual tertentu dengan menggunakan simbol toten dan dipimpin oleh pemimpin tertinggi masyarakat Toani Tolotang yang disebut Uwatta dan pembantu-pembantunya yang disebut uwa. Peranan kepemimpinan uwatta dan uwa mencakup seluruh aspek kehidupan masyarakat Toani Tolotang. Dalam peristiwa yang berhubungan dengan lingkungan hidup dan alam seperti: kelahiran, perkawinan, kematian, menaiki rumah baru, turun sawah, panen, dan upacara, peranan $u w a$ terutama $u$ watta sangat menentukan. Sekurang-kurangnya pelaksanaan upacara-upacaranya harus mendapat persetujuan dan restu $u w a$ atau uwatta.

Semua bentuk aktivitas budaya dan tradisi yang dianut oleh masyarakat Toani Tolotang, termasuk di dalamnya penetapan hukum-hukum adat (paseng dengan segala konsekuensinya), kepemimpinan spritual (uwatta dan $u w a$ ), pemakaian ungkapan (bahasa), pemakaian simbolsimbol adat, pelaksanaan upacara-upacara ritual, serta hubungan pergaulan antarmasyarakat Toani Tolotang memberikan peluang adanya indikasi ketidakadilan gender. Analisis gender terhadap masyarakat di Sulawesi Selatan, khususnya masyarakat etnik Makassar menunjukkan adanya pembagian peran pria dan wanita sebagai simbol budaya (Iswari, 2010; Daeng, 2012).

Untuk mengetahui secara pasti manifestasi gender yang terdapat dalam struktur budaya masyarakat Toani Tolotang ini, perlu dilakukan penelitian secara mendalam. Sebelumnya, Arfah \& Faisal (1991) menulis tentang Budaya Spritual Masyarakat Toani Tolotang di Amparita, Kabupaten Sidenreng Rappang ini. Akan tetapi, fokus ulasan mereka adalah nilai-nilai luhur budaya spiritual tersebut.

Penelitian ini bertujuan untuk mendeskripsikan kedudukan dan pembagian peran gender dalam struktur budaya spritual masyarakat Toani Tolotang. Manifestasi peran gender dalam struktur budaya tersebut diklasifikasikan menurut hukum adat, upacara ritual keagamaan, pesta adat (kelahiran, perkawinan, kematian, keselamatan, dan lain-lain), dunia pendidikan, rumah tangga, serta interaksi dan pengambilan keputusan (pertemuan antarwarga) di lingkungan masyarakat Toani Tolotang.

\section{METODE}

Sesuai karakteristik objek penelitian, penelitian ini dilaksanakan dengan menggunakan pendekatan kualitatif. Pendekatan ini digunakan dalam pengumpulan data pada latar alamiah dan peneliti bertindak sebagai instrumen kunci (Moleong, 1990). Sebagai instrumen kunci, peneliti menggunakan landasan berpikir fenomenologis dalam usaha memahami indikasi suatu gejala atau peristiwa sebagaimana adanya, yakni memahami kedudukan dan pembagian peran (konstribusi) gender dalam struktur budaya spritual masyarakat Toani Tolotang serta indikasi ketidakadilan gender dalam berbagai bentuk struktur budaya tersebut.

Data penelitian ini adalah informasi tentang kedudukan dan pembagian peran (konstribusi) gender dalam struktur budaya spritual masyarakat Toani Tolotang yang menjadi subjek penelitian. Subjek penelitian ini diambil dari hasil pengamatan terhadap upacara ritual keagamaan, pesta adat, hukum-hukum adat, dunia pendidikan (lembaga sekolah), lingkungan rumah tangga, pertemuan antarwarga, serta data dari informan, yakni pemangku adat yang memiliki pengetahuan yang khusus/ penting tentang kebiasaan-kebiasaan atau struktur budaya masyarakat Toani Tolotang.

Teknik yang digunakan dalam pengumpulan data pada penelitian ini adalah teknik observasi, wawancara mendalam (indepth-intervie), dan focuss group discussin (FGD). Teknik analisis yang digunakan dalam penelitian ini adalah analisis kulitatif deskriptif. Pekerjaan analisis ini mencakup analisis selama di lapa- 
ngan dan analisis setelah data terkumpul. Analisis yang dilakukan selama di lapangan, meliputi kegiatan seperti: (1) mempersempit studi sesuai fokus yang ditetapkan, (2) mengajukan pertanyaan analitik dalam menelusuri data, (3) membuat memo skematik penelitian, dan (4) secara terus-menerus melakukan kajian pustaka di lapangan.

Analisis setelah data terkumpul dilakukan dengan menggunakan analisis gender, yakni kombinasi analisis gender model fungsionalisme struktural (status quo) dan analisis gender model konflik (feminisme radikal, Marxisme, dan sosial) (Fakih, 2000). Tahap-tahap yang ditempuh dalam menganalisis data ini adalah mengidentifikasi dan mengorganisasikan data, mengklasifikasikan, menyortir, dan membuat kategorisasi data.

\section{HASIL DAN PEMBAHASAN}

Kepercayaan masyarakat Toani Tolotang tersebut melahirkan klasifikasi strata sosial yang sangat rentang melahirkan ketidakadilan yang diterima secara sukarela (hegemoni) oleh pengikutnya secara turun-temurun. Ketaatan kepada Uwatta dan Uwa yang dianggap sebagai wakil Tuhan menyebabkan ketidakadilan dalam kelas sosial masyarakat. Ketidakadilan itu mengarah kepada penindasan suatu kelompok strata atas (status quo), yaitu kelompok Uwatta dan Uwa terhadap masyarakat strata bawah (masyarakat pengikut).

Klasifikasi strata sosial dan kewajiban-kewajiban yang harus dipenuhi oleh masyarakat bawah kepada status quo (Uwatta dan Uwa) dalam berbagai aktivitas kehidupan, khususnya dalam ritual keagamaan menyebabkan penindasan ekonomi dan pemiskinan ekonomi bagi kalangan masyarakat bawah, sedangkan kalangan atas semakin kuat dengan keadaan ekonomi yang semakin mapan. Ketidakadilan ekonomi ini lebih ditopang oleh pandangan kebendaan pengikut Toani Tolotang. Penganut kepercayaan Toani Tolotang tidak mengenal istilah kaya. Kekayaan yang ada pada mereka bukanlah milik mereka, melainkan milik Dewata SeuwaE. Karena Uwatta dan Uwa dipandang sebagai wakil Dewata SeuwaE, barang-barang yang dimiliki masyarakat biasa sewaktu-waktu dapat diambil oleh Uwatta jika dia inginkan.
Bentuk ketidakadilan yang lain yang muncul sebagai manifestasi dari kepercayaan Toani Tolotang dan pengangungan terhadap kelompok Uwa dan Uwatta adalah dalam hal penentuan jodoh (perkawinan) dan perceraian. Perkawinan dan perceraian hanya boleh terjadi jika direstui oleh Uwatta dan Uwa. Pemuda dan gadis yang saling mencintai tidak boleh melangsungkan pernikahan jika tidak disetujui oleh Uwatta dan Uwa. Anak golongan Uwa (khususnya untuk anak gadis) harus menikah dengan yang segolongan untuk menjaga kemurnian darah. Demikian pula halnya dengan suami dan istri yang sudah tidak memiliki kecocokan dan ketenangan dalam rumah tangga, tidak boleh bercerai jika tidak diizinkan oleh Uwatta dan Uwa. Jadi, di sini perasaan dan kebebasan individu (hak asasi individu/ manusia) dibatasi oleh pengaruh atau kekuasaan Uwatta dan Uwa.

Dalam sistem perkawinan, masyarakat Toani Tolotang membenarkan sistem perkawinan monogami dan poligami. Seorang laki-laki, khususnya golongan Uwa, dapat saja mengawini lebih dari satu wanita dan pada umumnya istri-istri mereka hidup secara rukun. Akan tetapi, wanita Toani Tolotang khususnya yang berasal dari golongan $U w a$ tidak menikah lagi apabila suaminya meninggal. Realitas ini menyiratkan manifestasi ketidakadilan gender. Seorang wanita harus tetap memelihara kesetiaannya kepada suaminya meskipun sang suami telah meninggal, sedangkan laki-laki tidak. Seakan-akan kebutuhan biologis wanita ikut mati bersama dengan kematian sang suami.

Sistem pembagian kerja dalam rumah tangga masyarakat Toani Tolotang hampir tidak berbeda dengan masyarakat Bugis pada umumnya, yaitu suami berkewajiban mencari nafkah dan istri bertanggung jawab mengurus anak dan rumah tangga. Akan tetapi, karena tuntutan ekonomi dan perkembangan peradaban, banyak pula wanita Toani Tolotang yang turut membantu suaminya bekerja mencari nafkah. Akibatnya, kaum perempuan bekerja lebih keras dengan waktu yang lebih panjang (double-burden). Ironisnya, karena laki-laki dianggap sebagai pencari nafkah sehingga apa saja yang dihasilkan oleh kaum perempuan dianggap sebagai sambilan atau tambahan yang kadangkala tidak dihitung, tidak dianggap, atau tidak dihargai. 
Masyarakat Toani Tolotang memandang anak yang mereka miliki (laki-laki dan perempuan) memunyai kedudukan dan hak yang sama. Oleh karena itu, dalam sistem pewarisan anak laki-laki dan perempuan mendapat bagian yang sama besar. Demikian pula halnya dalam pemberian kesempatan memperoleh pendidikan. Anak laki-laki dan perempuan mendapat kesempatan dan hak yang sama untuk memperoleh pendidikan, baik pendidikan dalam lingkungan keluarga maupun pada sekolah-sekolah formal. Tinggi-rendahnya pendidikan penganut kepercayaan Toani Tolotang biasanya justru disebabkan oleh strata sosial. Pada umumnya, anak-anak golongan Uwa memiliki peluang mengecap pendidikan lebih tinggi dari anak masyarakat biasa. Hal ini dibuktikan oleh realita bahwa banyak anak Uwa yang menempati posisi yang tinggi pada lembaga-lembaga pemerintah, baik lakilaki maupun wanita.

Manifestasi ketidakadilan yang disebabkan oleh status quo juga tampak pada pengambilan keputusan dalam masyarakat. Masyarakat biasa dapat saja berembuk atau bertukar pikiran dalam membicarakan atau memecahkan masalah yang dihadapi oleh masyarakat Toani Tolotang. Akan tetapi, pada akhirnya keputusan akhir ditetapkan oleh Uwatta atau Uwa.

\section{DAFTAR PUSTAKA}

Arfah, M. \& Faisal. 1991. Nilai-Nilai Luhur Budaya Spritual Masyarakat Toani Tolotang di Amparita Kabupaten Sidenreng Rappang. Departemen Pendidikan dan Kebudayaan, Ujung Pandang.

\section{SIMPULAN}

Simpulan yang dapat ditarik sebagai temuan penelitian ini sebagai berikut. Pertama, kepercayaan masyarakat Toani Tolotang melahirkan klasifikasi strata sosial yang sangat rentang melahirkan ketidakadilan yang diterima secara sukarela (hegemoni) oleh pengikutnya secara turun-temurun. Manifestasi ketidakadilan yang disebabkan perbedaan strata sosial (status quo) dalam masyarakat: munculnya kesaan perbudakan, penindasan dan pemiskinan ekonomi, pengekangan dalam pengambilan keputusan (khususnya dalam masalah perkawinan dan perceraian), perbedaan kesempatan memperoleh pendidikan yang lebih tinggi, dan pengekangan dalam pengambilan keputusan.

Kedua, manifestasi ketidakadilan gender yang disebabkan oleh kepercayaan masyarakat Toani Tolotang adalah: perasaan dan keputusan individu dibatasi oleh status quo (ketidakbebasan dalam menentukan pilihan hidup), pembatasan gerak dan produktivitas wanita yang sedang hamil, kesetiaan istri terhadap suami yang melampau batas (wanita Toani Tolotang khususnya golongan Uwa yang ditinggal mati suaminya dianjurkan untuk tidak menikah lagi), pembagian peran dan beban kerja wanita yang lebih berat (khususnya dalam masyarakat biasa), kurangnya penghargaan terhadap hasil kerja wanita.

Daeng, Kembong. 2012. Gender dalam Syair Kelong Makassar. Jurnal Retorika, 8 (1): 37-43.

Iswary, Ey. Perempuan Makassar: Relasi Gender dalam Folklor. Yogyakarta: Ombak.

Moleong, Lexy J. 1990. Metodologi Penelitian Kualitatif. Bandung: Remaja Rosdakarya. 